"Whose right to the city? /Quel droit à la ville? »

\title{
The Publicness Paradox: Young People And The Production Of Parochial Places
}

\author{
Mattias De Backer
}

revues.org

Electronic version

URL: http://eue.revues.org/1428

ISSN: 1916-4645

Electronic reference
Publisher

Institut national de Recherche scientifique Urbanisation Culture et Société 


\title{
The Publicness Paradox: Young People And The Production of Parochial Places
}

\author{
Mattias De Backer
}

\section{Introduction}

1 In a 2007 TED Talk critic and author James Howard Kunstler argued: "the public realm in America has two roles: it is the dwelling place of our civilisation and civic life, and it is the physical manifestation of the common good." Degrading public space means degrading civic life and the common good, leading to "places not worth caring about." In other words, public spaces are symbolic for the state of our society. And Glenn Greenwald, the Guardian journalist who was the original contact person of whistle-blower Edward Snowden, said in a 2014 TED Talk: "the measure of how free our society is, is not how it treats its good, obedient, compliant citizens, but how it treats its dissidents and those who resist orthodoxy." ${ }^{2}$ Coincidentally, the way we treat out public spaces and our dissidents is exactly what this paper is about.

Many assumptions underlie concepts such as public space and seldom are they made explicit in the public debate. To what social realm does the term refer? Does 'public' mean everyone belongs there? Or is the opposite the case: public space is a place that is 'for' no one, as an empty container, a place of thoroughfare? Who decides on what the dominant order is and how is it installed and policed? In this paper I will investigate what constitutes 'publicness' by building on research with young people hanging out in public space. In the fieldwork undertaken between 2013 and 2016 in Brussels with young people between 11 and $25^{3}$, questions were asked regarding their relation with and in public space, focusing on spatial, social and affective aspects to being-in-public: how is public space and its publicness negotiated by youngsters? Which interactions occur? How are hanging spots produced? How are control and regulation perceived? To what extent does control or accessibility affect their sense of belonging? Which ambiences are produced in public space and what effects do they have on other users? These questions were posed in 
interviews and focus groups with 48 young people in total. Additionally, approximately 115 hours of observation were done in five cases (Jacht-Jourdan, Chicago, Peterbos, SintGuido and Kuregem), all of them in Brussels, Belgium.

3 In this paper I will first explore some public space literatures specifically addressing the question of publicness, after which I will consider the explicit or implicit conceptualisations of 'publicness' that were uttered by the participants themselves. Secondly, I will suggest we reconsider young people's being in public space and the nature of public space itself by building on the concept of 'parochial realm' as Lofland (1998) proposed it. By doing so I hope to show that young people (or potentially any group of people) can manifest themselves in public space by forming groups and temporarily claiming space. They do this out of the need to be among themselves, away from the adult gaze. Inadvertently or not, while hanging out they violate or bend formal and informal rules that structure (behaviour in) public space. Here the clash occurs between the adult society and the need of young people's having a place for themselves, between a temporary youthful appropriation and a permanent adult order. I will argue with Brighenti (2010) that the 'public' is not a group of people but a condition; one is in public. The paradox embedded in 'publicness' is that in order for young people to truly be in public they have to break or bend the rules of that public; a person can only be in space when that space becomes of that person.

\section{Publicness}

4 In the literature, definitions for public space are legion. Carr et al. (1992) and Carmona et al. (2008) emphasise accessibility as the central characteristic of public space, while Walzer (1986) and Sennett (1970) stress the fact that within public space we are by definition among strangers, people who are not our relatives or friends. Lofland $(1973 ; 1998)$ uses the same criterion to distinguish the public from parochial and private realms. In her seminal work on lower Manhattan, Jane Jacobs (1961) treats public space as a lively place filled with a large diversity of uses and users. For this author diversity is essential to constitute something truly public. Fraser (1990) emphasises the role of the "body of private persons" assembled to discuss matters of "public concern" or "common interest"' (Fraser, 1990: 58). 'Publicity' or 'publicness' can mean: 1) state-related; 2) accessible to everyone, 3) of concern to everyone; 4) pertaining to a common good or shared interest (Fraser 1990: 71). All these factors are somehow embedded in a highly elusive term like 'public space'.

Also Hannah Arendt discusses this multitude of meanings. She distinguishes between 'public' as (1) 'publicity' and 'public' as (2) the world itself "as far as it is common to us" (Arendt, 1998: 53). It is an informative distinction, because it stresses the fact that publicness can only be achieved if there is inter-visibility and appearance:

It means, first, that everything that appears in public can be seen and heard by everybody and has the widest possible publicity. For us, appearancesomething that is being seen and heard by others as well as by ourselvesconstitutes reality. (Arendt, 1998: 50)

However, 'publicness' also signifies something we have in common, or so it would seem. "To live together in the world means essentially that a world of things is between those who have it in common, as a table is located between those who sit around if, the world, 
like every in-between, relates and separates men at the same time" (Arendt, 1998: 53). It is the stuff that makes us related.

While several factors play a role in what establishes 'publicness', the physical domain itself is also subject to change. A large body of work has been devoted to the contemporary threats to public space. Urban researchers found that security and private interests have been prioritised in recent decades, transforming public space into a series of highly regulated sites of consumption-based activity (Low \& Smith, 2006). Certain behaviours have been curbed, limiting civil liberties like the right to protest, to dissent, to be heard, the right to be homeless or not to consume (Mitchell, 2003). Public space has been sanitised, exorcising difference as a result (Sorkin, 1992), often in the context of private leisure and consumption practices. Some argue that public spaces are rapidly becoming spaces of homogeneity and social control; they've become closed and closedminded (Dixon et al., 2006; Walzer, 1986).

These evolutions have seduced some commentators to declare the end of public space (Mitchell, 2003) or the end of street-culture (Valentine, 1996). Although critics have argued that these authors are perhaps too America-centred and that public space is still among the living in Europe's plazas and squares (Merrifield, 1984), there is reason enough to pay closer scrutiny to phenomena that are threatening the 'publicness' of public space. It is undeniably the case that certain phenomena and evolutions are putting pressure on our public spaces: surveillance and control, exclusion of the urban undesirable, hightechnology individualism (mp3-players, cell-phones, tablets), privatisation, gated communities, defensible spaces (Newman, 1972) and military urbanism (Davis, 1992), semi-privatisation in commercial pseudo-public spaces, and the occurrence of non-places (Augé, 1995) with highways, airports and malls as the archetypical examples. Among these evolutions, many are directly or indirectly related to an increased state of control. Surveillance measures have mushroomed: security cameras, drones, private security firms, community guards, police patrols, park guards, etc. As a result, certain behaviours have been curbed, limiting civil liberties like the right to protest, to dissent, to be heard, the right to be homeless or not to consume (Mitchell, 2003).

Public space is produced and policed against the backdrop of ideological assumptions about the meaning and value of public life, of what it means to be-in-public, what 'our' society stands for, reproducing particular versions of public order. One of these assumptions is that public space is 'for everyone'. This slightly romantic notion refers to a radical inclusive ideal of publicness (Young, 1990). In the contemporary urban setting several publics are sharing public spaces. It is the 'natural' state of this domain. This is why Scheffer (2007) champions the concept of 'shared space'. We share a public space that makes discord viable, allows it, recognises it. We share responsibility, but that does not mean we are one, or we agree per se. Discord is the natural state of a society (Visker, 2008: 428), like a table that divides and unites at the same time, in the metaphor of Hannah Arendt. The individual finds himself or herself almost certainly with strangers, people that we often view as non-persons (Proshansky, 1978: 166); or with whom we are "co-present", in Lofland's (1973) terms.

But research shows that the everyday negotiation of public space does not exactly live up to this ideal. In their study of people's perceptions of and opinions on street drinking in Lancaster (UK), Dixon et al. (2006) find that respondents say drunkards in public space distort the private/public distinction; they appropriate public space as if it is their living room. Other users feel that such behaviour limits their access to and free use of public 
space. In such a rationale undesirables are kept out because they curb the liberties of 'normal citizens'. In the perceptions and opinions they are also symbolically excluded, as non-persons, as undesirable. The material and symbolic inclusivity of public space is in fact prompted by the wishes of the dominant groups (Lehtovuori, 2005: 34-5; Harvey, 1973). In this symbolic order rights of access are in effect hierarchically graded. There might be a guarantee of the right to speak in public forums, but that is quite different from the question of effective access to that forum by those who need to speak in the street (Mitchell, 2003: 73).

11 Another assumption is that public space is pacified and consensual. In Rousseau's theory of consensus humans are egoist animals that decide it is better to sacrifice their egoism for the greater good of social organisation. The construction of a society requires rules and regulations for all of its members, so that they could live together with their new values (Graham, 1970). The famed 'social contract' consists of an invitation to become free by obeying the law of society, a law that expresses the common interest and the status quo. In this analysis the common good is in everyone's particular interest, a good bargain. Nancy Fraser's (1990) seminal text on "rethinking the public sphere" is instructive here. Referring to the work of the German humanist philosopher Jürgen Habermas she explains how "the bourgeois public was never the public. On the contrary, virtually contemporaneous with the bourgeois public there arose a host of competing counterpublics, including nationalist publics, popular peasant publics, elite women's publics, and working class publics" (Fraser, 1990: 61). However, these publics are "situated in a single 'structured setting' that advantages some and disadvantages others" (Fraser, 1990: 68). This structured setting is planned, managed, controlled and policed by the dominant moral apparatus. More recently, Michael Warner (2005) considered as 'counterpublics' those subordinate, subaltern and historically stigmatised publics that are defined by their tension with or opposition to a larger public. The bourgeois public of Habermas' time was perhaps not the only, but they dominated the public sphere nonetheless. It is perhaps the dominion of such groups and publics that gives public space the appearance of a peaceful realm.

12 A third assumption is that the boundaries between public and private and the meaning of these terms is fixed. However, this boundary is never fixed, a priori or naturally given, instead it is permeable and ideological in nature, often disadvantaging subordinate social groups (see among others Cahill, 2000). Soja (2000) argues that we need to pay attention to how public space is conceptualised as a fixed construction. Although public space is diminishing in certain parts of the world, the distinction between public and private has never been clear-cut (Lumsden, 2016). Today we're experiencing a restructuring of both these domains and a reconceptualisation of the distinction. According to HoussayHolzschuch (2016) public space is constructed into the private/public dichotomy that sees publicness as a given, whereas we should consider publicisation and privatisation as processes. She believes there is no consensus on what it exactly is or does, or what kind of uses and behaviours are expected.

The same goes for 'public order'. "[P]ublic order is not order per se, but rather entails managing the thresholds within which disorder is acceptable" (Brighenti, 2010:32). While public space is messy, there are tendency to 'clean up' public space. As a result everyday conflicts are reduced to 'nuisance' (Corijn, 2013). Keeping the order, policing, private surveillance, anti-social behaviour orders (ASBOs), all of these operate in the same spirit of cleanliness. As Tsoukala (2010) notes, rather than addressing offenses 
police forces increasingly focus on conflict prevention. And Tonry (2010) argues that the use of ASBOs in public space policy does not address the nuisances or offenses they were designed for but primarily have an expressive function: it serves "at least as much to acknowledge public anxieties as to accomplish anything substantive." (Tonry, $2010: 388$ ).

Everyday, mundane conflict and visible dissent cut through these assumptions. Mitchell $(1995 ; 2003)$, for instance, foregrounds contestation as a crucial element in understanding public space. Appropriation of public space by homeless, panhandlers or young people hanging around are an essential element of public life, as are complaints, discussions, quarrels, the calling of the police, fistfights, harassment, etc. Contrary to some euphoric accounts of some authors, the public and public space are not necessarily comfortable places to be in. 'The public' is not only an idea, it has an odor, it is loud and annoying, it is dressed in many shades of grey, and sounds like a choir that sings out of tune. L'enfer c'est les autres, a hell of which you are part. This smell of the crowd is the olfactory translation of Young's normative ideal that "open and accessible public spaces and forums one should expect to encounter and hear from those who are different, whose social perspectives, experience and affiliations are different" (Young, $1990: 131$ ). As a society, however, we seem to like interactions to be orderly and manage them accordingly.

\section{Young People's Experience Of Publicness And Control}

If publicness is co-created by all of a city's actors, then, surely, young people's opinions on and experiences with the topic are instructive. Many young people have had one or more experiences with other users of public space that addressed them about their behaviour. Rayane $(17, \mathrm{~m})$ tells the story of an elderly woman complaining to him and his friends when they were playing football.

Rayane: One day we were playing football, at least, we were standing there and giving some passes, and an elderly woman started shouting and said that we had to stop.

Me: Did she live in the neighbourhood?

Rayane: Yes.

Me: And what do you think of this?

Rayane: I thought we could play there. There weren't any cars around, it's a

big, open space. It wasn't late, around 4 in the afternoon and we weren't very noisy.

Me: What happened?

Rayane: We kept playing for a half-hour extra and then we left. Me: Didn't you think she'd call the police?

Rayane: No, because if she had they couldn't have done anything. We didn't do anything wrong.

In this and many other conversations young people showed how they were aware of the dominant rules; they know what is acceptable and what isn't. I found that their basic position is to comply with these rules.

Cheb Khaled $(18, \mathrm{~m})$ is understanding about why the police stopped him and his friends one time. He thinks they did because they were in a group, "perhaps because such a group makes some people feel unsafe." He says he understands the logic used by the police but he feels young people have a right to hang out as well, even if they are in a 
group. His testimony reads like a ritual or a game, rather than something that needs to be taken seriously.

Me: What do they do when they ask for your passport?

Cheb Khaled: They ask for your ID and they check your pockets or your schoolbag. And then they say something like 'go away, go to that place.'

Me: They tell you to go elsewhere?

Cheb Khaled: Yes.

Q: But it is your own neighbourhood, no?

Cheb Khaled: Yes, but ten minutes later we just come back.

Not only through rules, but also in their interaction with other users publicness is negotiated. Meryem $(13, \mathrm{f})$ was addressed by an elderly women about her behaviour.

\begin{abstract}
Meryem: I don't appreciate that. Public space is for everyone, not only for her. If she wants silence she should go to her place. And that she doesn't harass me ("qu'elle me casse pas la tête").

Me: But what then do you think of the rules in public space?

Meryem: We shouldn't exaggerate [in our behaviour] but in fact we are still somewhat free. Space is for everyone but we shouldn't exaggerate, we'd better not do stupid things like lighting firecrackers.
\end{abstract}

Contrary my participants' understanding of control measures and their compliance vis-àvis rules and authority, they consider it important that public space is a place of 'free access'. Luca $(13, \mathrm{~m})$ and Stefano $(14, \mathrm{~m})$ tell the story of a store manager urging them to go hang out somewhere else: "There is no sign there that says 'private'. It's a staircase, what could we do wrong? And he didn't even let us finish talking, he simply said to leave." There the boys found out rights of accessibility are negotiated constantly, and therefore have much to do with power. In another interview, Othmane $(13, \mathrm{~m})$ and Younes $(11, \mathrm{~m})$ explain how older youngsters appropriate the local skatepark in the evening and how that frightens them, especially with the dogs they have with them, the alcohol they drink and the weed they smoke. In se, they frown upon these transgressions, but their matter-of-factly tone suggests such interactions are part and parcel of being-inpublic and that they realise that at other moments of the day they are the ones that are claiming the skatepark.

Many accounts of young people on publicness relate to the accessibility and inclusivity of those places. One would therefore assume that regimes of control and regulation are regarded with suspicion or considered detrimental to these young people's free movement in the city. This appears not to be the case. The participants in my research express a high tolerance towards control measures and infrastructures. Gzifa (19, f) for instance thinks Brussels needs more security cameras. She would object to cameras in her own house but for the rest privacy is not an issue for her. Jihane $(17, \mathrm{f})$ says she feels comfortable because police officers often patrol the neighbourhood. Rayane $(18, \mathrm{~m})$, when talking about control in downtown Brussels, says he doesn't mind cameras and other forms of control. "It is normal." And when there are cameras someplace he still goes there. It is important to note here that in general girls and young women are more in favour of control for security reasons. Public space is heavily gendered, especially in Brussels, where ethno-religious aspects within the large Muslim community reinforce certain patterns of gendered socialisation, also in public space. As a result, there is a huge difference between the experience of publicness and control among girls and boys: 
Nouhaila $(19, \mathrm{f})$ : Girls are not inclined to do pranks or mess around like boys, like, in general. Girls do not hang out in the street; we move from A to B. But I can imagine that for boys, when there is a camera in a place they hang out, it isn't agreeable.

21 The inward-looking Peterbos neighbourhood has virtually no CCTV cameras, apart from the one hanging above the entrance of Le Turc's shop and everybody knows it doesn't work. It only serves as a deterrent. Interestingly, the boys interviewed distinguish between cameras in their own neighbourhood and the ones in the city centre. In the city, that's where they do not feel at home, so there it is allowed to formally control the crowds. In their own neighbourhood, however, they would feel annoyed with the presence of these cameras. "That would be like someone hanging a camera in my room." To be controlled in a place you consider your own is weird. "Outside, that doesn't bother me, because that's public." Several of my participants, especially boys, express a more critical opinion on control. Perhaps not surprisingly, these boys live in stigmatised neighbourhoods that are relatively intensely policed and controlled, with high occurrences of stop-and-search initiatives by the police.

Othmane $(12, \mathrm{~m})$ and Youssef $(13, \mathrm{~m})$ emphasise the right to express themselves.

Othmane: I accept that there are cameras for when someone steals or something, but I think children shouldn't be controlled too much. We need our freedom to express ourselves and to do what we want. People shouldn't be controlled too much, especially children.

While Faiza and Elizabeth (both 18, f) say that they are already constantly supervised and controlled "so cameras won't make a difference." This is an interesting point. Young people's tolerance towards control may stem from their being used to be controlled and supervised in other milieus of socialisation: school and home.

Cameras do, in some cases and for some young people, affect their feelings of belonging, even if they're not planning on doing something wrong. Hakim $(14, \mathrm{~m})$ points out that these control mechanisms have as a result that people are increasingly inclined to call the police or do nothing when something happens in the street, rather than intervene themselves. This he thinks is strange, especially for a neighbourhood where "everyone knows everyone." Rayane $(18, \mathrm{~m})$ says something similar. To him cameras come across as something normal but he wouldn't like one in his own street. "I don't know why. There is nobody there, so why would you need cameras? I don't see the purpose of a camera; it needs to stay somewhat private, no?" He feels strongly about the neighbourhood he lives in; he feels he really belongs there. Cameras would change that.

During the observations in Brussels I noticed a wide variety of overt and covert control infrastructures are present, ranging from private security and CCTV cameras to ordinary objects like fences and sadistic street furniture (Van Melik et al, 2008). The boys in Peterbos explain how they use a certain fenced off football pitch daily but never go to, or are never allowed to go to a basketball court nearby. The latter is always closed and serves no purpose. The neighbourhood has many more 'useless' terrains, like the rough concrete plateau on top of an underground parking lot. These leftover places can be important for young people's spatial practices, especially in dense environments. At first glance, fences are constructed as measures to keep intruders out. This is the case in the childcare facility in Kuregem, for instance. Since the Lemmens Square is known for its 
delinquent youth and alleged drug-trade, the owners or managers of the facility are not only preventing people from coming in, they are conveying a message. As James (2015: 62) reports on a youth club in East London being fenced off and consequently being the object of vandalism: "the real purpose of the fence was not to physically prevent entrance to the site but-like the gated community-to make a statement of force, construct a threat and locate a moral territory" outside the borders of the premises and into the neighbourhood. Curiously, when being asked what they thought of the fences in Peterbos, the boys answered they did not mind. On the contrary, to them it seemed these fences were there to protect them from the outside world, rather than they're being a restriction. Boundaries can, it seems, generate a feeling of cosiness and belonging.

Many public spaces in Brussels have visible signs of regulation that are at first sight not taken very seriously by the majority of the users. Even though some accounts concerning our surveilled and militarised cities (see for instance Davis, 1992) may be indicative of a worldwide trend, a large proportion of the Brussels city region is only relatively controlled and regulations are acted upon as if they are ostensibly noncommittal. Signs in the street may appear strict but conflicts are negotiated ad hoc. At the same time, most participants are in favour of rules and regulations structuring interaction in public space.

Me: Are there parks that are closed at a certain moment? Why is that?

Hakim $(14, \mathrm{~m})$ : That's because people wouldn't hang out in there constantly.

Me: Do you have the feeling you're controlled?

Hakim: Yes [he nods reassuringly, as if he wants to say "I know and that's quite normal"]

This is also what Othmane $(12, \mathrm{~m})$ and Youssef $(13, \mathrm{~m})$ say. Perhaps the framework of rules and regulations feels reassuring. Simultaneously, such a framework seems to be an invitation for improvisation. Rayane $(18, \mathrm{~m})$ explains how rules in a certain park may be limitative, but that's not a problem "because there are always places you can go to, places that are open 24/7." Even if they feel they are not welcome in certain places at certain times, there are always other places to go to.

Outside their home neighbourhoods, in locations like downtown Brussels (the Grote Markt is remarkably popular), the commercial area around the Nieuwstraat or the corporate landscape near the North station, control regimes are much more prominent. However, none of the participants said they felt inhibited to go to these places. One could conclude that reports on exclusive and militarised cities are gross exaggerations but I think we need to work on the publicness/control predicament with a much more subtle toolbox. Denis Wood (2010) identified three components of a spatial setting: physical dimensions, interactional rules, and the values and meanings expressed. The latter component is relevant here. The question of ownership and the articulation of rules is not straightforward; rules of public space are not always self-evident, and are often contradictory (Cahill, 2000: 267). Underneath this web of (discursive) informal and formal rules is a layer of sensations and affects that have an impact on everyday actions and interactions. One of these layers is the phenomenon I like to call 'parochiality'.

\section{Parochiality}

In our search for 'publicness' it is important to realise a variety of relations and realms occupies public space. Authors such as Lofland (1973; 1998), Strauss (1961) or Goffman 
(1956) have shown how relations between and interactions among individuals change the nature of public space. Lofland (1973) for instance, argues that young people in a group produce a mobile home territory, a domain in which they can be among themselves, an inbetween spot among peers. The production of such a territory temporarily 'privatises' (or 'parochialises' as I will argue below) public space. Essential in this phenomenon is that it is produced in a group (as Cheb Khaled guessed correctly above). This behaviour challenges the assumption that the public domain is there for everyone or that it can only be a neutral context for ephemeral passages (Sorkin, 1992). Musicians, young people, tourists, beggars, drunkards, they are all groups whose very act of 'privatising' public space can annoy other users (see Dixon et al., 2006).

Strauss (1961) distinguishes 'locations' and 'locales', the former indicating public spaces that present a physical segregation of lifestyles; locations are places where only persons of similar values and identities are likely to be found. 'Locales', on the other hand, are public areas that attract different sorts of populations. And Goffman (1956) talks of 'regions', which may be defined as

any place that is bounded to some degree by barriers to perception. Regions vary, of course, in the degree to which they are bounded and according to the media of communication in which the barriers to perception occur. Thus thick glass panels, such as are found in broadcasting control rooms, can isolate a region aurally but not visually, while an office bounded by beaverboard partitions is closed off in the opposite way. (p. 66)

31 In her 1998 book The public realm, Lofland develops the terms 'parochial' realm, as a third party in the public-private dyad. The public realm, to her,

is constituted of those areas of urban settlements in which individuals in copresence tend to be personally unknown or only categorically known to one another. Put differently, the public realm is made up of those spaces in a city which tend to be inhabited by persons who are strangers to one another or who 'know' one another only in terms of occupational or other nonpersonal identity categories (for example, bus driver - customer). (Lofland, 1998: 9; original emphasis)

The private realm, on the contrary is characterised by "ties of intimacy among primary groups members who are located within house-holds and personal networks" (ibid.: 10). It can be seen as the world of the household and friends networks, while the public realm is the world of strangers and 'the street' and the parochial realm is the world of the neighbourhood, of the workplace, of acquaintances networks.

The parochial realm, where the dominant relational form is communal, has a different atmosphere for those inside and outside. Parochial places can be offensive, provoking, impressive; and they are often exclusive and exclusionary in nature. As a youngster, a group is very important during identity-formation. The quest for intimacy is projected spatially into what Sloterdijk (2005) dubs 'solidarity circles'. Directed towards the outer world, these groups tend to 'perform' hanging out, very much in the sense Goffman (1956) means when he speaks of front-stage behaviour. When directed inwards (often literally) these youngsters can discuss and refine their performance. In the protected bubble of solidarity they are able to manifest themselves, their autonomy and independence of adults. This mechanism could perhaps also explain occasional acts of vandalism or graffiti: they are emblems with which they transform public space into their 
domain (Karsten et al., 2001) (Kamal (16, m) explicitly links graffiti to publicness, as an act of claiming a domain that is not yours to take). Many young people reconstruct parts of public space, or they transform it after dark when adults have retreated into their homes (Corrigan, 1979; Matthews et al., 2000).

These spaces are much valued by young people, especially during the evening, because of the physical and social isolation they afford. In essence, these have become private places where young people can congregate and hang out without fear of adult intervention. (Matthews et al., 1998: 197)

\section{local and temporary appropriation:}

With their bodies they lay claim to public spaces, pursuing activities of their choices, activities not intended in the design or program of these spaces. To do so, they use the physical features of their surroundings when they find those features helpful, and overcome or ignore them when they are constraining. (Franck \& Stevens, 2007: 35)

I argue that this type of use of public space is reason for annoyance with other users. However, that is probably not the full explanation for the public outrage directed at young people hanging out and the social construction of hangjongeren (Dutch pejorative term for young people hanging out).

Parochiality can be understood as an atmosphere of familiarity among friends or acquaintances (often in public space). Such an atmosphere, I believe, can be either delimited to a specific location-for instance by a few boys hanging out on a bench-or can extend to a larger scale, perhaps even a whole neighbourhood. Where the former is a simple translation of Lofland's (1998) parochial realm to a specific place, the latter form does not feature at all in Lofland's original understanding of the parochial realm. Parochiality can be produced on a specific location: a square (the Parvis in the Chicago neighbourhood), a street (Heyvaert, Kuregem), a street corner, a park (the one near Jihane's (17, f) home, Sint-Guido) or leisure area, etc. The skate park in Jacht-Jourdan is a clear example. Certain spots in the neighbourhood are well known among young people, so they go there in the hope of finding acquaintances there spontaneously.

Cheb Khaled (18, m): You see each other often, but it's not a particular group. Rather, you see that person often with that other one and you meet them once in a while. It's not necessarily a group with everybody together.

Hicham $(18, \mathrm{~m})$ : Sometimes you see this one friend here and then there. For example, first in the youth club and then later at the football field. Sometimes, you're with ten people when you decide to play football.

Me: How do you get together? Do you go there, like, randomly or how does that happen?

Cheb Khaled: A bit of both. Sometimes you just meet after school and sometimes you send a text.

37 I also encountered many instances of parochiality on a larger scale. In Peterbos, for example, "everyone knows everyone", Souhail $(17, \mathrm{~m})$ says. Bakr, my gatekeeper in the area, explains "knowing one another" is slightly exaggerated: "knowing one another is simply knowing each other's first name. The youngsters and perhaps those that are 30 and 40 , they know each other to a certain extent." A remarkably similar story was told by Cheb Khaled $(18, \mathrm{~m})$ when he talked of his Anderlecht neighbourhood. The atmosphere of 
familiarity results in a feeling of freedom among my participants there. Other inhabitants of the quartier might feel annoyed sometimes, because of noise for instance, but these things are always taken care of internally. Police is only called in the event of a burglary or a theft, for instance. "There is not much vandalism," says Bakr, "because it's our neighbourhood, right?" And if something does go wrong first les grands-young adults with authority and an example function-step in. Chicago is a similar neighbourhood where parochiality is potentially a prominent part of public life. Bilal $(25, \mathrm{~m})$ explains living together with people with the same background makes interaction in the neighbourhood much easier.

However, not everyone can benefit from this context of familiarity. Several girls, for instance, voice their concerns in terms of feelings of insecurity and relate them directly to the threatening atmosphere in the street. In fact, most examples of parochiality I found, also during observations, were male dominated. Jihane $(17, \mathrm{f})$, for instance, would like there to be more public space in her neighbourhood "because the space that we have is always taken." Younger boys like Ayoub $(13, \mathrm{~m})$ may experience the same phenomenon. In fact, during our encounter at the skate park older boys came closer, listening in to what he said which clearly intimidated him to the extent that he soon stopped answering altogether. Tarek $(17, \mathrm{~m})$ speaks of people "you don't know" and equates this with fear and insecurity. Similarly, Stefano's $(14, \mathrm{~m})$ parents didn't allow him to leave the house when they lived in Sint-Gillis-they lived in a lively and diverse neighbourhood. He was granted more freedom once the family lived in Sint-Lambrechts-Woluwe, "a much safer area, much cleaner streets."

The picture remains diffuse. Dalila $(18, \mathrm{f})$ muses nostalgically about the atmosphere in the street where she used to live in Morocco:

I don't know anybody who lives in the same apartment building. No social life, nothing. In Morocco you could stay out until 12 and still there would be plenty of people in the street. Here shops close at six and everyone goes home.

Gzifa $(19, \mathrm{f})$ is just as enthused about the atmosphere she knew back in Africa when everyone knows everyone. "If you have a problem everybody knows and they will talk to you and say 'everything okay?' and you will eat together." The close-knit community she describes contrasts sharply with the individualised and threatening atmosphere she experiences in Brussels. We can't therefore conclude parochiality is either comforting or threatening to girls across the board. Nouhaila $(19, \mathrm{f})$, for instance, really appreciates the friendly atmosphere she encounters during her walks in the Chicago neighbourhood.

41 Parochiality does seem to refer to in-group and out-group dynamics captured by Tajfel (1974) and others in the so-called 'social identity theory' (see also Tajfel et al. 1971). The former refers to the affinity one experiences with a group of peers, which is expressed through strong ties and favouritism. The latter is usually expressed in a negative way: outsiders of the group are perceived as a threat or treated in a derogatory fashion, they are discriminated and excluded. Both dynamics show that the forming of groups depends on boundaries, expressed by insiders (group membership) and outsiders (group categorisation). Such dynamics, especially when they take place in public space, materialise in atmospheres such as parochiality.

42 One important footnote is necessary here. Since the forming of groups and their group memberships in public space is highly volatile, we need a fluid understanding of insider/ 
outsider dynamics. Sometimes they hang out with fixed friends groups, but mostly the composition and size of groups and the context of hanging out change constantly. As I argue elsewhere (see De Backer, forthcoming), the groups that are formed in public space are perhaps best understood in Matthews et al.'s (1998: 196) notion of 'microculture': "microcultures are created by combinations of personalities, the locations they make their own and the events they share. Together these provide common and unifying sets of experiences."

\section{Discussion}

43 Is public space an inclusive realm for everyone, pacified and consensual and are the meanings of public and private fixed and timeless? Not at all. My research seems to suggest that young people's negotiations of control and their interactions with others are nuanced and multifaceted. Young people are aware of the dominant order and their go-to position is to comply with rules. It seems to them as well accessibility and inclusivity is important. One would expect that, as a result, control is regarded with suspicion. That is not the case. Their attitude towards control infrastructures is nearly always positive. This tolerance is perhaps related to the fact that control is already present in all the arenas of their life. Also in much more intensely controlled areas such as malls or shopping districts, they say they feel relatively free and at ease. In their home environments, some of my participants say control, for instance in the form of CCTV cameras, would feel strange, because it is their territory. Control affects belonging, but that effect is not necessarily positive or negative. In the case of Peterbos, fences seem to engender feelings of safety and cosiness, whereas cameras in that same neighbourhood would be perceived as threatening. The research seems to suggest that control can be accepted in those domains that are 'out there', places they can 'public'. In their home environment, control would be strange.

I also found quite some instances of how regulations and interactions 'on the ground' are negotiated ad hoc. Young people perceive this constant, everyday negotiation as an essential element of publicness. But at the same time they prefer a framework of rules, maybe because such a framework would feel reassuring. It is also an invitation for improvisation: "if we're not welcome here and now, we'll just go elsewhere, or we'll come back later." This shows that young people consider is up for debate. An important element I have foregrounded in this paper is the fact that public space's publicness can be transformed, especially by groups. Building on Lofland's (1998) notion of the parochial realm, I propose that parochiality is transformation of public space, an alteration of its inclusive atmosphere, a temporary claim to an otherwise open domain.

The atmosphere of familiarity among acquaintances in public space, either on a specific location or in a whole neighbourhood, can generate feelings of belonging and ownership, of being at home. But not everyone always benefits from this atmosphere. Parochiality is comforting, welcoming, for the insider. That is less the case for an observer or passer-by that is not part of that parochial bubble. Parochiality can also be considered as a largely unconscious act of resistance against the dominant control infrastructure, to the rules and regulations of the powerful. But such parochiality is highly flexible. Parochiality may be used as a tactic of young men against the dominant control infrastructure, but it may simultaneously exclude young women from public space as a result of their over public space. This means that young people can be both vulnerable and oppressive, victim and 
offender at the same time, or that they can switch between roles depending on the circumstances. This also means we should consider publicness in a model that is more than one-dimensional between top-down control and bottom-up transgressions.

Rather than analysing young people's behaviour against the dominant moral apparatus and its prescription of desired or acceptable behaviour I argue for an open matrix that considers individuals and groups as possessing their own means of exerting power. Although literature suggests that young people, along with other urban undesirables, are victims of the closing off and 'neutralising' of public space, I agree with Soja (2000) that we need to pay attention to how public space is conceptualised as a fixed construction.

When seen in simply dichotomous terms, there is a tendency to see changes in public space simply as a kind of undemocratic transfer to the private domain, resulting in an incontrovertible loss of civic freedom. Such thinking universalizes and homogenizes the public realm - as well as the privatization process - and protects them from critical examination of how each is also affected by other processes of differentiation and change. (Soja, $2000: 320$ )

Public space is a continuum with (top-down) regulations and infrastructures of formal control on the one hand and (bottom-up) social mechanisms of informal control, appropriation and parochialisation on the other hand.

Young people's claiming a place of their own is often exclusive and 'anti-social'. Appropriating public space means that other groups are scared or pushed away. Much of this behaviour is rather innocent but the fact remains that their gathering of bodies affects the feelings of passers-by, residents or outsiders, and potentially also alters their behaviour. In neighbourhoods with a strong parochial atmosphere the same phenomenon occurs on a larger scale, with visitors feeling out-of-place (several young people reported they felt uneasy in neighbourhoods where they didn't know anybody). That is possibly also why these areas are termed 'no go' areas by outsiders.

What I tentatively call the publicness paradox is exactly this: in a reaction to exclusionary mechanisms urban undesirables can take over public space themselves or even produce an atmosphere that feels threatening to outsiders. Monifa $(17, \mathrm{f})$, when asked what the neighbourhood lacks, argues for a place apart for young people; she'd rather not disturb the adults. But others are more adamant in their complaint. This exposes the paradoxical nature of publicness to the fullest. In order to be truly social, young people as well as other undesirables need to be asocial: "by claiming space in public, by creating public spaces, social groups themselves become public. Only in public spaces can the homeless, for example, represent themselves as a legitimate part of 'the public'," (Mitchell, 2003: 129) but as a result of their being in public they can and in fact do sometimes exclude other users.

"What makes a space public - a space in which the cry and demand for the right to the city can be seen and heard - is often not its preordained 'publicness'. Rather, it is when, to fulfil a pressing need, some group or another takes space and through its actions makes it public. The very act of representing one's group (or to some extent one's self) to a larger public creates a space for representation. (Mitchell, $2003: 35$ )

Even if the legal discourse states that spaces and discourses ought to be devoid of force, violence and dissent, "it is only by being 'violent' or forceful that excluded groups have gained access to the public spaces of democracy" (Mitchell, 2003: 52). 
Brighenti (2010) argues 'public' is not a group of people; it is a condition:

one cannot be the public, one can only be in public: the public, in other words, is 'bridging' rather than 'bonding'. (...) If the public cannot be equated with any minority group, least of all can it be equated with the majority. Rather, the point is to image the public as a register of interaction and a regime of visibility. (Brighenti, 2010: 19-20)

According to this author, a space's publicness is constituted of three elements: intervisibility, accessibility and resistance. Publicness is more than interaction and free movement, conflict is what makes something 'public'.

The public domain thus offers a productive notion of publicness, in which the public is not understood merely through the 'grand dichotomy' - the opposition of the public to the private - rather it is observed as a selfconsistent regime of social life. The public domain is a movement consisting of a series of always reversible situational appropriations; it is a territory of affection defined by visibility, accessibilty and resistance. (Brighenti, 2010 : 40)

Publicness does not belong to anyone, it is not a good that can be confiscated, it is an action, an activity; it is being-in-public on a temporary stage of a world-in-common. The public becomes, by making it visible. "If the public seems to presuppose the existence of the common, it is because we could not make anything public without some degree of commonality-at the very least, a commonality of beholders attesting that things come into existence" (Brighenti, 2015 : 315). The author continues by saying that a common can be considered a de-essentialised version of a community. Curiously, such a 'deessentiallised community' is exactly what can be witnessed in the parochial realm.

\section{Conclusion}

In this paper I argue that several assumptions on what constitutes publicness are turned upside down when we consider the role of conflict and negotiation in interactions in public space. In fact, I argue, with Mitchell (2003) and Brighenti (2010) that conflict is what makes a space public. That's what I call the publicness paradox: in order for young people (or other urban undesirables) to be in public they have to violate the rules that govern that same public, they have to privatise, or rather, 'parochialise' it. In order to be truly social, young people need to be asocial. Being-in-public is not a romantic cohabitation of strangers. The public realm is organised by principles such as cooperative movement, avoidance of contact and indifference towards the other. As Lofland (1973) has shown, a crowd is in fact a collection of private bubbles.

Sloterdijk's (2005) beautiful metaphor of humanity as 'foam' is instructive here. Seen from farther away foam looks like a homogeneous and viscous entity, while at closer scrutiny it is a collection of bubbles each separated from the other with a membrane of its own. Humanity prefers to organize itself in various smaller and bigger circles. With every circumscription that draws people together a new border is inscribed in the social fabric. The boundaries, the conflicts, the bustle of the throng, those are what constitutes publicness: "people who speak, all with different accents, intonations, pitches, voices, gestures: here is the social element, the true chaos of discordant heterogeneities" (Tarde, 1999 : 74). 

Heiner Mühlmann: "the inclination to exclude (that is, the classification of humanity in friend and foe) is natural and inborn" (Sloterdijk, 2009 : 293). In Sloterdijk's spherology, paranoia is the ultimate expression of a sensus communis. What we share is Arendt's table, the boundaries that separate us in Sloterdijk's imagery. Such a vision of being-in-public is pessimistic about the possibility to have something truly in common, except our boundaries. Perhaps that means that a politics of togetherness (Amin, 2012) may never be able to transform feelings of distrust, awe, uprootedness, xenophobia, conservatism, etc. or overcome parochialism, nationalism and other isms relating to notions of community. resolution techniques can be put into practice to tackle fears and aversions between communities, to bridge social and cultural distance by working on a common urban project. Young (1995), similarly, argues that urbanites are prepared to encounter people that are not 'like them'. How else can you explain that inhabitants of a city seek out situations where they are among large numbers of strangers on a daily basis? Difference takes place in the city, where a common identity based on a shared past does not exist. In a city there can only be pragmatic cohabitation and an urban project oriented to the future.

Brighenti (2015) believes notions of civility and urbanity are being transformed as we speak, with a new culture of publicness suited to the new plural territorializations of the city being developed in ways not yet recognised and codified (Brighenti, 2015: 309).

If to make a commonality we need a place in common, the point is that the conditions for such places to appear are being transformed before our eyes by the newly emerging regimes of interaction, the new urban circulations, ambiances, and atmospheres. (Brighenti, $2015: 324$ )

How can such a new urbanity overcome boundaries? On the basis of the data I have gathered concerning young people's negotiation of public space, it seems parochial, but de-essentialised versions of community are constitutive of publicness. Are these parochial bubbles 'new' and therefore our hope for the future? It is probably too early to tell.

\section{BIBLIOGRAPHY}

Amin, A. (2012). Land of strangers, Cambridge, Polity Press, 205 p.

Arendt, H. (1998) [1958]. The human condition, $2^{\text {nd }}$ edition, Chicago, University of

Chicago Press, $370 \mathrm{p}$.

Augé, M. (1995). Non-places. Introduction to an anthropology of

supermodernity, London, Verso, $122 \mathrm{p}$.

Brighenti, A.M. (2010). The publicness of public space. On the public

Domain, Quaderno 49. Trento, University of Trento, 56 p. 
Brighenti, A.M. (2015). « The public and the common. some approximations of their contemporary articulation », Critical Inquiry, vol. 42, no 2, p. 306-328.

Cahill, C. (2000). « Street literacy: urban teenagers' strategies for negotiating their neighbourhood ", Journal of Youth Studies, vol. 3, no 3, p. 251-277.

Carr, S., Francis, M., Rivlin, L.G. \& Stone, A.M. (1992). Public space, Cambridge, Cambridge University Press, 400 p.

Carmona, M., Magalhaes, C.D., \& Hammond, L. (2008). Public space. The management dimension, London \& New York, Routledge, $232 \mathrm{p}$.

Corijn, E. (2013). « Maatschappelijk conflict tot overlast reduceren... », Orde van de dag/Kluwer, vol. 61, p. 13-19.

Corrigan, P. (1979). Schooling the smash street kids, Basingstoke, Macmillan

Publishing, $158 \mathrm{p}$.

Davis, M. (1992). « Fortress Los Angeles: the militarization of urban space ». In

Sorkin M. (ed.), Variations on a theme park: the new American city and the end of public space, New York, Noonday Press, p. 154-180.

Dixon, J., Levine, M. et R. McAuley (2006). « Locating impropriety: street drinking, moral order, and the ideological dilemma of public space ", Political Psychology, vol. 27, no 2, p.187-206.

Franck, K. \& Stevens, Q. (2007) (ed.). Loose space: possibility and diversity in urban life, London \& New York, Routledge, 303 p.

Fraser, N. (1990). « Rethinking the public sphere: a contribution to the critique of actually existing democracy », Social Text, vol. 25/26, p. 56-80.

Goffman, E. (1956). The presentation of self in everyday life, Edinburgh, University of Edinburgh 255 p.

Graham, G.J. (1970). « Rousseau's concept of consensus », Political Science

Quarterly, vol. 85, no 1, p. 80-98.

Harvey, D. (1973). Social Justice and the City, London, Edward Arnold, 354 p.

Houssay-Holzschuch, M. (2016). « Diss \& ditch? What to do with public space »,

In De Backer, M. , Melgaço, L., Varna, G. et F. Menichelli (eds.), Order and conflict in public space, London, Routledge, p.216-220.

Jacobs, J. (1992) [1961]. The death and life of great American cities, New

York, Vintage Books, 458 p.

James, M. (2015). Urban multiculture: youth, politics and cultural

transformation in a global city, Basingstoke, Palgrave Macmillan, 216 p.

Karsten, L., Kuiper, E. et H. Reubsaet (2001). Van de straat? De relatie jeugd

en openbare ruimte verkend, Assen, Van Gorcum, $158 \mathrm{p}$. 
Lehtovuori, P. (2005). Experience and conflict: the dialiectics of the production of public urban space in the light of new event venues in Helsinki 1993-2003, Helsinki, Centre for Urban and Regional Studies Publications/Espoo, 32 p. Lofland, L.H. (1973). A world of strangers. Order and action in urban public space, Prospect Heights, Waveland, $223 \mathrm{p}$.

Lofland, L.H. (1998). The public realm. Exploring the city's quintessential social territory, New Brunswick and London, Aldine Transaction, 305 p.

Low, S. et N. Smith (2006). The politics of public space, New York \& London, Routledge, $200 \mathrm{p}$.

Lumsden, K. (2016). « Boy racer culture and class conflict: urban regeneration, social exclusion and the rights of the road ", In De Backer M., Melgaço, L. , Varna, G. et F. Menichelli (eds.), Order and conflict in public space, London, Routledge, p.160-181.

Matthews, H., Limb, M. et B. Percy-Smith (1998). « Changing worlds: the microgeographies of young teenagers », Tijdschrift voor Economische en Sociale Geografie, vol. 89, no 2, p. 193-202.

Matthews, H., Limb, M. et M. Taylor (2000a). « The street as thirdspace », In Holloway, S. et G. Valentine (eds.), Children's geographies: living, playing, learning, London, Routledge, p. 63-79.

Merrifield, A. (1994). « Public space: Integration and exclusion in urban life », City, vol 5-6, p. 57-72.

Mitchell, D. (1995). « The end of public space? People's Park, definitions of the public, and democracy ", Annals of the Association of American Geographers, vol. 85, p. 108-133.

Mitchell, D. (2003). The right to the city: social justice and the fight for public space, New York, The Guilford Press, 270 p.

Newman, O. (1972). Defensible space - crime prevention through urban design, New York, MacMillan, 264 p.

Proshansky, H. (1978). « The city and self-identity », Environment and behavior, vol. 10, no 2, p. 147-169.

Scheffer, P. (2007). Het land van aankomst, Amsterdam, De Bezige Bij.

Sennett, R. (1970). The uses of disorder: personal identity and city life, New York, Knopf. 198 p.

Sloterdijk, P. (2005). « Foreword to the theory of spheres ». In Ohanian M. et J.-C. Royoux, Cosmograms, New York \& Berlin, Lukas and Sternberg, p. 223-241.

Sloterdijk, P. (2009). « The Nomotop ", Law and Literature, vol. 18, no 1, p. 1-14. 
Smith, N. (1996). The new urban frontier: gentrification and the revanchist city, New York \& London, Routledge, 262 p.

Soja, E. (2000). Postmetropolis: critical studies of cities and regions, London, WileyBlackwell, $440 \mathrm{p}$.

Sorkin, M. (1992) (ed.). Variations on a theme park: the new American city and the end of public space, New York, Hill \& Wang, 252 p.

Strauss, A. (1961). Images of the American City, New York, The Free Press of Glencoe, $306 \mathrm{p}$.

Tajfel, H., Billig, M.G., Bundy, R.P. et C. Flament (1971). « Social categorization and intergroup behaviour ", European Journal of Social Psychology, vol. 1, no 2, p. 149-178.

Tajfel, H. (1974). « Social identity and intergroup behaviour », Social Science Information, vol. 13, p. 65-93.

Tarde, G. (1999) [1893]. Monadologie et sociologie, Paris, Les empêcheurs de penser en rond, $150 \mathrm{p}$.

Tonry, M. (2010). « The costly consequences of populist posturing: ASBOs, victims, 'rebalancing' and diminution in support for civil liberties ", Punishment and Society, vol. 12, no 3, p. 387-413.

Tsoukala, A. (2010). « Combating football crowd disorder at the European level: an ongoing institutionalisation of the control of deviance ", Entertainment and Sports Law Journal, vol. 7, no 2, p.lv.

Valentine, G. (1996). « Children should be seen and not heard: the production and transgression of adults' public space », Urban Geography, vol. 17, no 3, p.

205-220.

Van Melik, R., Van Aalst, I. et J. Van Weesep (2007). « Fear and fantasy in the public domain: the development of secured and themed urban space », Journal of urban design, vol. 12 , no 1 , p. 25-41.

Visker, R. (2008). « De stad als publieke ruimte », Ethische Perspectieven, vol. 18, no 3, p. 426-436.

Walzer, M. (1986), « Pleasures and costs of urbanity », Dissent, Fall, p. 470-475. Warner, M. (2005). Publics and counterpublics, New York, Zone Books, 334 p. Wood, D. (2010), « Lynch Debord: About two psychogeographies », Cartographica, vol. 45 , no 3, p. 185-200.

Young, I.M. (1990). Justice and the politics of difference, Princeton, Princeton University Press, $286 \mathrm{p}$. 


\section{NOTES}

1. TED TALKS. "James Kunstler: How bad architecture wrecked cities", You Tube, URL: https:// www.youtube.com/watch? $v=Q 1 Z e X n m D Z M Q$, published May $16^{\text {th }} 2007$, accessed September $20^{\text {th }}$ 2016, 21:41 minutes.

2. TED TALKS, "Glenn Greenwald: Why privacy matters", You tube, URL: http:// www.youtube.com/watch?v=pcSlowAhvUk, published October $10^{\text {th }} 2004$, accessed September $20^{\text {th }}$ 2016, 20:41 minutes.

3. The participants to the research have been given an alias in this publication, in accordance with the Journal's ethical guidelines.

\section{ABSTRACTS}

Many assumptions underlie a concept such as public space but seldom are they made explicit in the public debate. In this paper I will investigate what constitutes 'publicness' by building on research with young people hanging out in public space in Brussels. I will argue that young people, by meeting in public space, produce parochial places (Lofland, 1998). By doing so they transgress certain rules in public space. I will argue that the paradox embedded in 'publicness' is that in order for young people to truly be in public they have to break or bend the rules of that public; a person can only be in space when that space becomes of that person. The question then becomes if these forms of parochiality allow us to overcome the boundaries between people and communities, and between public and private.

\section{INDEX}

Keywords: public space, young people, parochiality, control, common 